\title{
Ungdata-rapportene kan gi et skjevt bilde av depresjon blant unge
}

Svarene i Ungdata-undersøkelsen ser ut til å bli overtolket i retning av symptomer på depresjon blant unge. Det kan føre til at man overser tegn på andre sykdommer.

\section{Beathe Presthus Asplund}

Helsesykepleier

Institutt for helse- og omsorgsfag, Universitetet i Tromsø - Norges arktiske universitet

\section{Anne Gerd Karlsen}

Førstelektor

Institutt for helse- og omsorgsfag, Universitetet i Tromsø - Norges arktiske universitet

Helsefremmende

Ungdom

Ungdata

\section{Hovedbudskap}

Det er ikke tvil om at depresjon blant unge blir fanget opp gjennom Ungdatas spørsmålsstilling. Likevel tror vi at en andel av svarene er indikasjoner på andre forhold enn depressive symptomer. Vi ønsker å $\varnothing$ ke bevisstheten om hva som er normalt ved unges psykiske helse. Kunnskap om variasjonene i unges pubertetsutvikling kan motvirke at forståelsen av det normale ved unges psykiske helse blir for smal. 
Depresjon blant unge har fătt stor oppmerksomhet de siste årene, og den nasjonale Ungdata-unders $\varnothing$ kelsen (1) er en mye benyttet kilde til informasjon om hvordan unges psykiske helse er.

I studien (2) som vi baserer denne artikkelen på, ble det tatt utgangspunkt i Ungdata-unders $\emptyset$ kelsen for å se nærmere på hva man vet om unges helse, og for å utforske hvordan forekomsten av depresjon og depressive symptomer hos unge er kartlagt. I studien ble det belyst at insomni har et symptombilde som likner det man finner ved depresjon, og det ser ut til at insomni og depresjon har omtrent lik forekomst $\mathrm{i}$ aldersgruppen.

Mange unge ser også ut til å ha en midlertidig forskjøvet døgnrytme, kombinert med at de sover mindre enn den anbefalte mengden. De unge er i en fase av livet hvor de bekymrer seg mer over sosiale situasjoner. De skal blant annet skape seg nye nettverk og løsrive seg fra sine foresatte, samtidig som de skal gjennom en fysisk og mental modningsprosess.

I tillegg påvirkes unge av ytre forhold som dårlig familie $\varnothing$ konomi og foresattes utfordringer, stress og vansker med å sette grenser for de unge. Alle disse forholdene ble i studien antatt å kunne innvirke på de kategoriene som Ungdata unders $\emptyset$ ker under temaet psykisk helse og depressive symptomer.

\section{Depresjon og insomni kan ha liknende symptomer}

Spørsmålene i Ungdata-unders $\varnothing$ kelsen (se faktaboks under) omhandler altså forhold som påvirkes både ved en depresjon og gjennom den normale pubertetsutviklingen, forhold som endret døgnrytme, færre timer søvn og endringer i sosiale roller og nettverk. 
Når svarene på de seks spørsmålene om psykiske helseplager slås sammen som depressive plager, mener vi at det er en risiko for at svarene overtolkes i retning av symptomer på depresjon. Dette kan føre til et skjevt bilde av forekomsten av depresjon blant unge.

I tillegg blir vurderingen av en unders $\varnothing$ kelse hvor det ikke er mulighet for kliniske intervjuer, ytterligere komplisert når to ulike sykdommer, her depresjon og insomni, kan fremtre med liknende symptombilder.

\section{Kartlegging av psykiske helseplager i Ungdata}

Ungdata kartlegger ungdommers psykisk helseplager fordelt på sju kategorier. Respondentene skal krysse av for om de i løpet av den siste uken har vært plaget av noe av dette:

1) Følt at alt er et slit

2) Hatt søvnproblemer

3) Følt deg ulykkelig, trist eller deprimert

4) Følt håpløshet med tanke på framtida

5) Følt deg stiv eller anspent

6) Bekymret deg for mye om ting

7) Følt deg ensom

Til hver kategori skal man angi sin respons på en skala fra 1-4, hvor 1 er «ikke plaget i det hele tatt», 2 er «lite plaget», 3 er «ganske mye plaget», og 4 er «veldig mye plaget» (3).

De som i Ungdata-rapportene omtales som å ha et «høyt nivå på depressive symptomer» (4, s. 80-81), omfatter de som i gjennomsnitt minst krysser av for at de er ganske mye plaget når svarene på de seks første kategoriene summeres (4). Spørsmål 7 om ensomhet behandles for seg i en egen skala.

\section{Samfunnsmessige problemer blir individualisert}


En for ensidig tolkning av resultatene til å være tegn på depressive symptomer kan føre til at man overser tegnene på andre sykdommer. Samtidig som det er viktig å ha oversikt over omfanget av en sykdom som depresjon hos unge, må man kunne skille sykdommene fra hverandre for å kunne gi riktig hjelp.

\section{«Det kunne være mer målrettet å sette søkelyset på andre forhold i de unges oppvekstmiljø.»}

En annen konsekvens kan bli at man individualiserer forhold som egentlig har sitt opphav i oppvekstmiljøet eller samfunnet ellers. På den ene siden ønsker man å kartlegge og avdekke problematikk hos enkeltindividet. Men på den andre siden kan den samme kartleggingen føre til at tiltakene hovedsakelig forstås og rettes inn på individnivå, selv om det kunne være mer målrettet å sette søkelyset på eksempelvis familieøkonomi, foreldres ressurser eller andre forhold i de unges oppvekstmiljø.

Det kommer frem i Ungdata 2020 (5), som er utgitt etter at studien vår ble gjennomført, at kategoriene beskrives under overskriften psykiske helseplager og ikke lenger slås sammen som depressive symptomer. I lys av den nevnte studien anser vi dette som en mer nyansert måte å presentere besvarelsene på.

\section{Mestringstro styrker unges helse}

Det er viktig å ta hensyn til ulike tolkninger av selvrapporterte symptomer i unders $\varnothing$ kelser som Ungdata før man velger tiltak rettet mot unges psykiske helse. Dette er særlig viktig å ta høyde for når en av kategoriene de spør etter, er søvn, og vi samtidig vet at døgnrytmen hos mange unge helt naturlig er forskjøvet, med den konsekvens for mange at de får mindre søvn (6-10). 
Denne døgnforskyvningen har en kjønnsforskjell, hvor jentene kommer tidligere i denne fasen enn guttene, samtidig som den er sterkere hos guttene når det etter hvert inntreffer (11). Slik vi ser det, kan det også være nyttig å se nærmere på om disse forholdene kan ha noe å si for kjønnsforskjellene i psykisk helse.

I tillegg vil vi belyse en mulig nytte av å dreie oppmerksomheten fra et sykdomsforebyggende til et helsefremmende perspektiv, gjennom å rette søkelyset mot mestringstro og ressurser, for å styrke unges helse.

\section{A håndtere utfordringer skaper motstandsdyktighet}

Gjennom studien vår kom det blant annet frem at mange unge sover langt mindre enn det som er anbefalt. Dersom dette er noe av det som fanges opp gjennom Ungdata-unders $\varnothing$ kelsen, er det nærliggende å anta at det er karakteristiske trekk ved pubertetsutviklingen som påvirker hvordan besvarelsene i Ungdata blir tolket, snarere enn at disse trekkene er et uttrykk for $\varnothing \mathrm{kt}$ depresjon alene.

Derfor vil vi videre beskrive hvordan en $\varnothing \mathrm{kt}$ bevissthet rundt det som er normalt ved unges psykiske helse og utvikling, kan bidra til og styrke et helsefremmende perspektiv $i$ arbeidet med unges helse.

Bandura (12) beskriver at det å mestre motgang skaper en opplevd motstandsdyktighet. Gjennom å håndtere stress og utfordringer utvikles det en styrke og en opplevelse av å kunne mestre tøffe situasjoner.

Motsatt kan det å bli fortalt at man mangler kapasitet til å mestre utfordringer, føre til at man unnviker utfordrende situasjoner, slik at man fortere gir opp i situasjoner hvor man kunne ha utviklet sitt potensial. $\varnothing \mathrm{kt}$ mestringstro styrker den fysiske helsen, reduserer stress og negative følelser og fører ofte til en bedre evne til å korrigere kroppslige feiltolkninger (12). 
Kunnskap om hva som er karakteristiske trekk ved pubertetsutviklingen, kan, slik vi ser det, være med på å normalisere utfordringer som oppstår. Dette kan man eksempelvis gjøre ved å gi informasjon til de unge og deres foresatte om at unges $s \varnothing v n m \varnothing n s t r e$ ofte endres, hvordan normale bekymringer er en del av de unges modning av hjernen (13-15), og at ungdomstiden naturlig innebærer endringer av sosiale roller og nettverk $(16,17)$.

\section{Søvnens positive egenskaper bør fremheves}

Med utgangspunkt i Banduras teori (12) mener vi at det vil være hensiktsmessig for de unge selv, deres foresatte og de som jobber med unge, å ha en forforståelse og en holdning til at menneskets hverdag innebærer både positive og negative følelser, og at livet har motgang som både vil tåles og mestres. Det kan være viktig at de unge har realistiske forventninger til livet nettopp fordi læring foregår gjennom å oppleve og erfare vanskelige ting.

Utfordringer skal ikke bagatelliseres eller overses, men balanseres med det å finne ens egen styrke og evne til å håndtere dem (12). Derfor er det viktig at unge har forbilder som viser at et stort spekter av følelser er normalt, og at det ikke er et enten-eller på det å kjenne lykke og velvære, og hvis ikke er du syk og deprimert. Hverdagen består av alt fra glede til sorg og bekymringer, og det er nettopp dette som gir oss mennesker mental vekst.

\section{«Kunnskap om søvnens effekt kan øke forståelsen av den fysiske helsen.»}

Studien viste videre at kunnskap om egen helse og søvnens effekt kan $\varnothing$ ke forståelsen av den fysiske helsen og redusere feiltolkninger av eksempelvis det å føle at alt er et slit, eller at man er trist, kjenner på bekymringer eller det å ikke få sove om kvelden. 
De positive egenskapene søvn gir, som bedre regulering av følelser, en positiv effekt på hukommelsen, bedre sosial kompetanse, bedre ordforråd, bedre forståelse for følelser og $\varnothing \mathrm{kt}$ sosialt engasjement, $b \varnothing r$ fremheves (6). Gjennom den nevnte studien (2) kom det frem at det ville være hensiktsmessig å formidle dette til både ungdom og deres foresatte. Slik vil ungdom selv kunne prioritere helsefremmende tiltak, som det å ivareta og beskytte sin egen $s \varnothing v n$.

I tillegg kan det være viktig å gi informasjon om hvor ungdom og deres familier kan få hjelp og støtte ved sosiale utfordringer i familier, ved foreldres sykdom eller dårlig økonomi, slik at man gjennom $\varnothing \mathrm{kt}$ kunnskap om egen helse og mulige hjelpetiltak selv bidrar til $\varnothing \mathrm{kt}$ mestringstro og mobilisering.

\section{Det er variasjoner i hva som er normalt}

Unges psykiske helse er et komplekst tema som ikke nødvendigvis bare har én riktig forståelsesramme.

Vi har her fors $\varnothing \mathrm{kt}$ å belyse det helsefremmende perspektivet og hvordan det kan bidra til en bedre opplevd helse og det å finne mening ved de utfordringene man kan møte på. Gjennom å ha kunnskap om variasjonene i hva som er normalt, kan man unngå at forståelsen av det normale ved unges psykiske helse blir for smal.

\section{Referanser}

1. Ungdata. Hva er Ungdata? [internett]. Oslo: Ungdatasenteret; [sitert 30.03.2021]. Tilgjengelig fra: http://www.ungdata.no/Om-undersoekelsen/Hva-erUngdata

2. Asplund BP. Bak tallene. En litteraturstudie om unges helse, hva kan vi avdekke gjennom Ungdatas spørsmål om psykiske plager? Troms $\varnothing$ : Universitetet i Troms $\varnothing$ - Norges arktiske universitet; 2020. 
3. Frøyland LR. Ungdata - lokale

ungdomsunders $\varnothing$ kelser. Dokumentasjon av variablene i spørreskjemaet. Oslo: NOVA, Oslomet; 2017.

4. Bakken A. Ungdata 2018. Nasjonale resultater. Rapport 8/18. Oslo: NOVA, Oslomet; 2018.

5. Bakken A. Ungdata 2020. Nasjonale resultater. Rapport 16/20. Oslo: NOVA, Oslomet; 2020.

6. Kaczor M, Skalski M. Prevalence and consequences of insomnia in pediatric population. Psychiatria Polska. 2016;50(3):555-69.

7. de Zambotti M, Goldstone A, Colrain IM, Baker FC. Insomnia disorder in adolescence: diagnosis, impact, and treatment. Sleep Medicine Reviews. 2018;39:12-24.

8. Owens JA, Weiss MR. Insufficient sleep in adolescents: causes and consequences. Minerva Pediatricia. 2017;69(4):326-36.

9. Pieters S, Burk W, Vorst H, Dahl R, Wiers R, Engels R. Prospective relationships between sleep problems and substance use, internalizing and externalizing problems. J Youth Adolescence. 2015;44(2):379-88.

10. Sivertsen B, Harvey A, Lundervold A, Hysing M. Sleep problems and depression in adolescence: results from a large population-based study of Norwegian adolescents aged 16-18 years. European Child \& Adolescent Psychiatry. 2014;23:681-9.

11. Hagenauer MH, Lee TM. The neuroendocrine control of the circadian system: adolescent chronotype. Frontiers in Neuroendocrinology. 2012;33(3):211-29. 
12. Bandura A. Exercise of personal and collective efficacy in changing societies. I: Bandura A, red. Selfefficacy in changing societies. Cambridge, New York: Cambridge University Press; 1995. s. 1-45.

13. Kendall P. Neurodevelopment: How does the teenage brain work? Nature. 2006;442(7105):865-7.

14. Plessen KJ, Kabicheva G. Hjernen og følelser fra barn til voksen. Tidsskrift for Den norske legeforening. 2010;130(9):932-5.

15. Lenroot RK, Giedd JN. Brain development in children and adolescents: insights from anatomical magnetic resonance imaging. Neuroscience and Biobehavioral Reviews. 2006;30(6):718-29.

16. Tetzchner S. Utviklingspsykologi. 2. utg. Oslo: Gyldendal Akademisk; 2012.

17. Haavet OR. Ungdomsmedisin. Oslo:

Universitetsforlaget; 2005. 